ammonia is cheaper than any other so far known, that the production of cheap nitric fertilizers is of a universal importance to the increase of food production, and that consequently the Haber invention was of the greatest value to the world at large.

3. The Haber method was invented and published several years before the outbreak of the great war. At the International Congress for Applied Chemistry held in the United States in 1912, it was described by Professor Bernthsen. The method was consequently known to all nations before the war and available to them to the same extent. It seems to have been put into practise in the United States.

4. Ammonia, the product of the Haber method, must be converted into nitric acid in order to give rise to explosives or to corrosive gases. As a matter of fact, the Haber plants in Germany were erected with a view to producing agricultural fertilizers.

5. As far as I know, no gas masks have ever been manufactured in Sweden. In all events, there existed in Sweden during the whole war an export prohibition on all sorts of war material. That prohibition has been rigorously upheld.

6. The Nobel Prizes are paid in one single post and not in monthly installments.

\section{DYE SECTION OF THE AMERICAN CHEMICAL SOCIETY}

THE second meeting of the Dye Section will be held in St. Louis, beginning Wednesday, April 14. At this meeting the committee on permanent organization will submit "By-Laws" for the consideration of the Section, the approval of which by the Section and by the Council, will be the necessary steps to the permanent organization of the Dye Chemists of the United States, as the Dye Division of the American Chemical Society.

The secretary asks all scientific workers in the field of dyes to present the results of their researches and experiences at these meetings of the dye chemists. Papers on the manufacture, properties or application of dyes, both of coal tar or natural origin, will be of timely interest. Any chemist having any such scientific information ready for presentation is asked to communicate at once with the secretary, giving subject and time for presentation.

As is usual, full details of the final program, time and place of meeting can be obtained by addressing Dr. C. I. Parsons, 1709 G. Street, N. W., Washington, D. C., or the undersigned. . R. Norris Shreve,

\section{Fifth Avenue,} NEW YORK CITY

Secretary

\section{SCIENTIFIC NOTES AND NEWS}

Rear Admiral Robert Edwin Peary, retired, the distinguished arctic explorer, died at his home in Washington, on February 20, from pernicious anemia, aged sixty-three years.

Professor E. G. Conkrin, of Princeton University, and Professor T, H. Morgan, of Columbia University, have been elected honorary members of the Belgian Society of Zoology and Malacology.

Dr. JoHN R. Swanton, of the Bureau of American Ethnology, and Dr. Truman Michelson, of the Bureau of American Ethnology and professor in George Washington University, have been elected corresponding members of the Société des Américanistes de Paris.

The Bulletin of the Johns Hopkins Hospital for December contains a record by Dr. Thomas S. Cullen, of the work and writings of Dr. Henry Mills Hurd, Baltimore, who was the first superintendent of the hospital.

Dr. JAMES Harris Rogers, of Hyattsville, Maryland, has received from the Maryland Academy of Sciences, Baltimore, its inventor's medal for his work on "underground and sub-sea wireless."

IT is stated in Nature that the council of the Glass Research Association has appointed Mr. R. L. Frink, Lancaster, Ohio, director of research. The secretary of the association says: "Mr. Frink has a lifelong experience of the American glass trade and glass research, is well known to the foremost English glass 